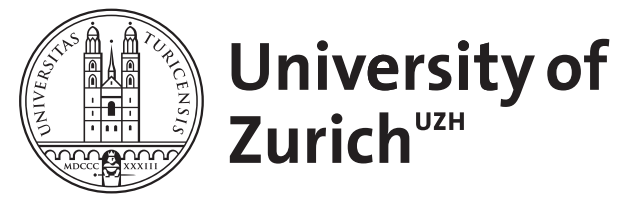

The prosecution service function within the Swiss criminal justice system

Gilliéron, Gwladys ; Killias, Martin

DOI: https://doi.org/10.1007/s10610-008-9070-y

Posted at the Zurich Open Repository and Archive, University of Zurich

ZORA URL: https://doi.org/10.5167/uzh-12291

Journal Article

Published Version

Originally published at:

Gilliéron, Gwladys; Killias, Martin (2008). The prosecution service function within the Swiss criminal justice system. European Journal on Criminal Policy and Research, 14(2):333-352.

DOI: https://doi.org/10.1007/s10610-008-9070-y 


\title{
The Prosecution Service Function within the Swiss Criminal Justice System
}

\author{
Gwladys Gilliéron • Martin Killias
}

Published online: 1 August 2008

(C) Springer Science + Business Media B.V. 2008

\begin{abstract}
The criminal justice system of Basel is described as a cantonal example for Switzerland. Special attention is paid to the Prosecution Service Function within this framework and its relationship to police and courts. The article not only refers to legal provisions but to the factual handling of criminal cases as well.
\end{abstract}

Keywords Cantonal report Basel City · Criminal justice system · Factual handling · Legal provisions $\cdot$ Public prosecution

\section{General}

Switzerland consists of 26 cantons. Recently, they were responsible for the proceedings as well as for the organization of the courts. As a consequence every canton still has its own criminal code of procedure. Additionally, there are three federal codes of criminal procedure. ${ }^{1}$ Since 1 April 2003, the new art. 123 par. 1 of the Federal Constitution is in force which grants - among others - the competence of legislation in the field of criminal procedure law to the federation. Based on this, a draft Swiss Code of Criminal Procedure was compiled which shall replace the 29 codes of procedure. The "Public Prosecution Service (PPS) model II"2 is taken as a basis. The cantons of Zürich, Basel-Stadt, Solothurn, Tessin, St. Gallen and Appenzell Innerrhoden are already close with this model. This harmonization is not only to

\footnotetext{
${ }^{1}$ In respect of federal, military and administrative criminal proceedings.

${ }^{2}$ Description of the model below.

Gwladys Gilliéron, Martin Killias: Translation from German into English by Mr. Litty

G. Gilliéron $(\bowtie) \cdot$ M. Killias

Institute of Criminology, Criminal Law and Criminal Procedural Law,

Law Faculty of the University of Zürich, Rämistrasse 74/39, 8001 Zürich, Switzerland

e-mail: gwladys.gillieron@rwi.uzh.ch

M. Killias

e-mail: martin.killias@rwi.uzh.ch
} 
increase the efficiency of criminal prosecution, but also to enhance legal certainty and equality.

\section{Overview of Different Inquiry Models Within Switzerland}

The applied inquiry models currently differ from canton to canton. They can be simply divided into four basic models, namely the examining magistrate models I and II plus the PPS models I and II. The models are now briefly exemplified.

Examining magistrate model I: The investigation is lead by an independent examining magistrate. The judicial police are under his control so there is no separation between investigation and examining. Consequently, proceedings are pooled. The examining magistrate starts proceedings at its own initiative, the CID acts on instruction. The PPS may not issue directives for the examining magistrate, within preliminary proceedings it appears just as a party. After completion of preliminary proceedings, the PPS has to give the bill of indictment and to represent the prosecution in court (Bundesrat 2006).

Examining magistrate model II: Examining magistrate as well as PPS act during preliminary proceedings. The examining magistrate is bound by PPS' instructions. The extent of this subordination differs from particular canton's law and practice. The modalities regarding the co-operation are different as well. While some cantons grant the power to stop proceedings and to charge to the examining magistrate, others allow only examinations and at the most the stopping of the proceedings. In a majority of the cantons, charging and prosecuting in court are exclusively done by the PPS (Bundesrat 2006).

PPS Model I The intervention of an independent examining magistrate as well as the dualbased proceedings are typical here. Before calling the examining magistrate, the CID directed by the PPS - performs investigations. Thereafter, the PPS orders the independent examining magistrate to implement examinations. During the examinations the PPS acts as a party, it is not entitled to issue instructions. After completion of examinations, the examining magistrate forwards the files to the PPS which decides whether to charge or end the case (Bundesrat 2006).

PPS Model II The absence of an examining magistrate is characteristic here. The PPS is "mistress" of preliminary proceedings, directs examinations, charges and prosecutes. The PPS leads the police or is entitled to issue instructions normally. The advantage of this model is the preclusion of a change of the official in charge, from examining magistrate to PPS. So a considerable expenditure of time and personnel is avoided (Bundesrat 2006).

This report cannot possibly consider the peculiarities of all codes of criminal procedure, so it is limited to the Code of Criminal Procedure ${ }^{3}$ of the Canton Basel-Stadt (Basel-City). This code as well as the draft of a Swiss Code of Criminal Procedure follow the PPS model II.

A simplified model of Switzerland's criminal justice system is shown in Fig. 1.

\section{Situation in the Canton of Basel-Stadt}

In the Canton of Basel-Stadt the PPS sticks fairly close to the German model. In the German system the PPS is a body of the judicature. It is responsible for enforcing the law and so quite strongly bound by the principle of legality. Therefore, cases of opportunity are

\footnotetext{
${ }^{3}$ As well as the organization of the courts.
} 




Fig. 1 Simplified model of the Criminal Justice System in Swizerland 
very restricted and only acceptable within a certain legal framework. So the principle of legality mainly applies. For the reality of German practice see Elsner \& Peters (2006).

Beside the standard proceedings leading to a public charge, there are four special types of proceedings, namely the "Verzeigung" procedure ${ }^{4}$, the direct levying of fines by police institutions ${ }^{5}$, private action proceedings und proceedings against absentees ${ }^{6}$.

\section{Classification of Criminal Actions}

According to art. 10 and 103 StGB (Swiss Criminal Code) criminal actions are classified as "Verbrechen" (serious crime), "Vergehen" (offence of normal gravity) and "Übertretung" (breach). Verbrechen are actions with a threat of imprisonment of more than three years (art. 10 par. 2, $40 \mathrm{StGB})^{7}$. The legal maximum punishment for Vergehen is imprisonment of up to three years or a fine (art. 10 par. 3, 34, $40 \mathrm{StGB})^{8}$, for Übertretungen a fine (art. 106 $\mathrm{StGB})^{9}$.

When the levying of fines is done by police institutions, offences are dealt with by administrative proceedings. These proceedings are appropriate when petty offences regarding cantonal ${ }^{10}$ or confederate ${ }^{11}$ law are present. The fines may not exceed the sum of CHF 300,-. There is no entry in criminal records since this happens only when a fine exceeds CHF 500,-.

\section{PPS}

\section{Organization}

The PPS is subordinated to the cantonal government and is led by the Chief Public Prosecutor who decides on the assignment of business. Furthermore, he supervises the progress of transactions, can issue decrees and can reverse decrees issued by personnel under his control as well as his ability to declare decrees as subject to his consent. The Chief PP ensures a lawful, representable and expedient carrying out of investigations and provides for a homogenous exercise of substantive criminal and criminal procedure law. The PPS consists of several divisions with varying degrees of autonomy with differing structures and functions. Beside the staff which is responsible for media contacts, education and training, personnel and budget administration as well as IT-support, there are four divisions: The criminal investigation division, the universal division, the division for economic crime and the juvenile division. Every division's head is a "leading public

\footnotetext{
${ }^{4}$ Leads to a remission of a penal order, see III.2.2.

${ }^{5}$ See V.3.

${ }^{6}$ The last two types of proceedings will not be enlarged on.

${ }^{7}$ Till 31 December 2006, Verbrechen were actions with a threat of punishment of penitentiary (minimum duration: one year, maximum length: 20 years).

${ }^{8}$ Till 31 December 2006, the legal maximum punishment for Vergehen was imprisonment (length: three days up to three years).

9 Till 31 December 2006, the punishment for Übertretung was detainment (can last from one day to three months) or fine.

${ }^{10}$ By-law on the tickets to be handed out on the spot by police officers.

${ }^{11}$ Road Traffic Act.
} 
prosecutor" (section 2, By-law on the organisation of the PPS). The chief PP hands on the powers to

- issue distribution-of-business-plans in compliance with the maxim of the most equable distribution of work and issue necessary instructions regarding the execution of investigative procedures

- control acceptable and expedient carrying out of investigations

- ensure the homogenous exercise of criminal (procedure) law.

In the following the particularities of the various divisions are described:

The criminal investigation division (KriKo, Kriminalkommissariat): Receives the incoming reports, initiates investigation proceedings and takes measures such as: ascertaining the facts, collecting evidence, tracing and - if appropriate - arresting the perpetrators. It carries out the hearings of accused persons and witnesses, applies for detainment to the judge and establishes the court of jurisdiction. The division investigates all offences excluding such within the field of economic crime. The lead PP has the necessary amount of prosecutors in his division. Subordinated to the head of criminal investigation division are the staff, the IT bureau, the forensic science laboratory, the departments, the specialized sections and the CID analysis centre. The drug department ("Betäubungsmitteldezernat", BMD) investigates violations of controlled substances law and related offences. The forensic science department especially delivers expert opinions (e.g. fire inquest, comparisons of writings) and carries out forensics as well as appraisals of tracks.

The universal division (Allgemeine Abteilung): Completed investigation proceedings are normally transferred by the criminal investigation division to the universal division which decides - occasionally after supplemental investigations - whether to charge, drop or assign. So the cases of KriKo and BMD are brought to criminal court by the PPS of the universal division. This division consists of the lead PP, prosecutors, associate prosecutors, academic staff, investigation officers and assistants, office personnel and trainees. There are 15 PP jobs and 11 legal expert jobs (Verwaltungsbericht 2005).

The economic crime division: investigates complex economical crime cases and represents the prosecution in court on its own. Normally the division deals with the cases within its scope of responsibility from reporting to completion. Beside the PPs, the division consists of forensic personnel $^{12}$ and an audit section.

The juvenile division: investigates offences committed by juveniles and adolescents and represents the prosecution in the minors' court. The division consists of 24 persons: three juvenile prosecutors, ten forensics, six assistants in the social worker's group and five clerks.

\section{Powers Within the PPS}

Within the PPS, the following functions are considered to be judicial (section 1, By-law on the powers of the PPS)

- public prosecutors

- academic staff

- legal trainees

- CID officers, investigative officers, investigative assistants, detectives

- detached officers of the police and military sphere.

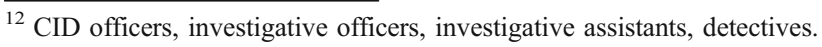


They are entitled to summon accused persons, witnesses, informants, experts and translators.

Beside the prosecutors, academic staff, CID officers and investigative officers are authorized to perform the following official functions (section 2, By-law on the powers of the PPS):

- interrogation of witnesses

- issuing to bring forward orders

- make a decision on granting visitations

- make a decision on release from police custody

- order of dactyloscopy and correlative measures

- issue of search warrants.

\section{Election and Appointive Authority}

The PPS completes tasks to fulfill the state's task to punish which is assigned to the executive power. So the PPS belongs to the executive power as well and is selected by this power. The chief PP, the lead PPs and the juvenile PP are selected after advertising by the main council (section 53, Para 1, GOG Basel-Stadt/Law on the organisation of the Courts of Basel-Stadt) for a term of six years. The other PPs, academic staff, CID und investigative officers are engaged by the cantonal government on suggestion of the PPS' executive board (section 53, Para 2, GOG Basel-Stadt) ${ }^{13}$. Also on its suggestion, the cantonal government appoints the number of jobs. The occupation as a public prosecutor requires a legal degree and Swiss civil rights.

\section{Case Control, Reporting and Inspection}

The transaction control unit tabulates all pending cases monthly. Moreover, all prosecutors are obliged to issue a backlog report on 1 April and 1 October each year. ${ }^{14}$ The Chief Prosecutor leads an inspection based on the report of 1 October yearly to review backlogs and to fix adequate target agreements (By-law on the supervision of the PPS).

The Power of the Superior Authority to Issue Instructions

The hierarchical structure of the authorities entitled to prosecute crimes corresponds with the power of the superiors to issue directions for subordinates. This may happen in general with regard to the manner of the functional tasks as well as referred to a single case. This power extends to discretionary decisions as well as to the technical realization of criminal proceedings or the application of the law. However, the directions have to remain within the legal order (Hauser et al. 2005). In the Canton of Basel-Stadt the cantonal government may induce the PPS to start proceedings but not to stop them (section 50 par. 2 GOG Basel-Stadt). It is acknowledged in practice today that any directions of the cantonal government are limited by the law. The PPS is autonomous and independent in a factual way regarding the functional scope, i.e. when fulfilling the tasks and in the decision practice, due to the rare exercise of the power of issuing instructions by the government (Hauser et al. 2005).

\footnotetext{
${ }^{13}$ It consists of the chief PP, the lead PPS and the juvenile PP.

${ }^{14}$ See also II.6.
} 
Supervising the PPS

Exerting his supervising duties, the cantonal government observes the activities of the PPS with concurrence of the Justice Commission. For that purpose, the government demands to be informed regularly by the PPS and the Justice Commission. In particular, the following is to be presented to the head of the Department of Justice care of cantonal government (By-law on the supervision of PPS):

- annual budget

- budget and annual accounts

- report referring to particular cases: When criminal proceedings against an officer, a member of an authority or a notary are initiated, the Chief Prosecutor has to inform the head of the department of justice immediately. Likewise he brings cases of a special range to the head's attention without delay.

- periodic backlog reports: Twice a year, in April and October, the Chief Prosecutor transmits a backlog report to the head of the Department of Justice. In this report all proceedings have to be considered which initiation is more than three months ago; in every of such cases reasons have to be given briefly for not having charged or dropped.

- visitation reports: At least once a year a member of the Justice Commission has to call on the PPS. At this occasion, the Chief Prosecutor and the lead prosecutors have to inform especially about backlogs, organizational issues and all important incidents. The visiting member reports to the head of the Department of Justice briefly.

\section{Court}

\section{Organization of the Criminal Court}

The criminal court consists of eight presidents, a governor, up to 15 regular and 18 replacement judges with partial legal education. Beside this, there are four penal order judges $^{15}$, likewise with a legal education.

The members of the criminal court have to complete different tasks: On a regular cycle the presidents are appointed judge for custodial issues and provide two members of the appeal body of the court. Furthermore, they build different three-judge courts and chambers or they act as single judges. These bodies have different powers to punish (Ruckstuhl et al. 1998). The president decides whether a case is to be committed to a chamber, a threesome court or a single judge. The PPS endorses his assessment regarding the competent division of the court based on investigation proceedings on the bill of indictment (section 36, GOG Basel-Stadt). Only a criminal court president may act as single judge who has the power to impose a term of imprisonment up to six months ${ }^{16}$. The three-judge court is built up by a president and two judges, whereof at least one must have a legal education. The court may impose terms of imprisonment of up to three years. ${ }^{17}$ The chamber consists of a president and five judges whereas at least one must have a legal education as well. This body has an

\footnotetext{
15 Their function will be described within the framework of the "Verzeigung" procedure at III.2.2.

${ }^{16}$ Since 1 January 2007, he has the power to impose a term of imprisonment up to six months.

${ }^{17}$ Since 1 January 2007, he has the power to impose a term of imprisonment up to five years.
} 
Table 1 Amount of court proceedings

\begin{tabular}{lll}
\hline & 2004 & 2005 \\
\hline Single judge & 518 & 465 \\
Threesome court & 246 & 248 \\
Chamber & 29 & 34 \\
Total & 793 & 747 \\
\hline
\end{tabular}

unlimited power to impose sanctions. Unlimited fines may be imposed by all court bodies. Regarding the measures, the single judge may only take ambulant measures; the three-judge court all measures except a placement. The chamber may take all measures, in particular placement.

Table 1 outlines the number of court proceedings in the different bodies of the criminal court (Verwaltungsbericht 2005).

Cases Brought to Court

\section{Regular Proceedings}

If preliminary proceedings ${ }^{18}$ (also called investigation proceedings) establish sufficient suspicious facts referring to a punishable action of the suspect, the PPS brings a charge (section 111 StPO-BS - Code of Criminal Procedure Basel-Stadt). Bringing a charge means that the PPS words the bill of indictment and transfers it, along with the relevant files, to the criminal court. The accused has no opportunity to contradict the charge. This disadvantage is compensated by the power of the court to drop the proceedings. The bill of indictment is very important because it fixes what the criminal court has to deal with (section 127 par. 2 StPO-BS). Only what has been stated in the bill of indictment can be the object of the criminal verdict. Therefore it must include, beside the exact name of the charged persons, the facts of the case the persons are blamed for and the criminal regulations the persons shall be convicted of.

By bringing a charge the proceedings go on to the main proceedings ${ }^{19}$ stage and the principles of accusation ${ }^{20}$ and immutability ${ }^{21}$ begin to come into effect. Moreover, all responsibilities shift to the instruction presidium which has to prepare the main trial.

\section{Realization of the Main Trial}

The court presidium is responsible for ensuring that the main trial can be carried out without delay. In the Canton of Basel-Stadt the main trial is oral (section 121 par. 2 StPOBS) and determined by the principle of immediacy (section 121 par. 3 StPO-BS). That requires that all hearings of evidence which are essential for judging the circumstances and forming a verdict have to be brought in the main trial. Furthermore, this also implies that the judges have no knowledge regarding the files before. So they start - without being biased - during the trial to find out in an oral and direct way what the accused is blamed of

\footnotetext{
${ }^{18}$ Proceedings from report until laying a charge.

${ }^{19}$ From reception of the bill of indictment until a verdict of the first court of law.

${ }^{20}$ The prosecution defines the subject of the trial.

${ }^{21}$ The subject defined by PPS may not be amended.
} 
and which evidence is to be found. Only the court's presidium which has to set up the trial, the clerk, the PPS and the defender have knowledge with regard to the content of the files. The principle of immediacy is damped a little by the opportunity of transferring single chapters of the files to the judges before the trial and providing less important evidence by reading out the files ${ }^{22}$.

The preparation of the main trial means in substance that a so-called evidence list is tabulated (section 114 StPO-BS). The list shows which witnesses, informants and other people $^{23}$ have to be called up und which pages of the files have to be read out. As a rule, the latter are the bill of indictment, expertises and other extensive or complex sections of the files. In place of tabulating the evidence list the presidium can return the files to the PPS in case of insufficient clarification from the preliminary proceedings (section 117 par. 1 StPO-BS). When a list of evidence is created, the PPS as well as the accused and his defender receive a copy of it. Currently the presidium of the court fixes a period of time during which amendments of the list of evidence can be required and additional evidence can be offered (section 114 par. 3 StPO-BS). This is the point of time to enter a plea as well evidence proposals.

In the main proceedings the PPS represents the state's penal powers and therewith the prosecution, equally in possible appeal proceedings. In the main proceedings the PPS is a party, i.e. it has, as the accused, just a right to propose the carrying out of special actions by the responsible criminal court's presidium.

The main proceedings take place in one of the five courtrooms of the criminal court. The trial in criminal court is principally public (section 121 par. 1 StPO-BS). The public can be barred from special hearings of evidence which concern strongly the personality of the accused $^{24}$, of witnesses or informants ${ }^{25}$.

The main trial can be subdivided into five stages:

1. Initiation of the trial

2. Evidence proceedings

3. Hearing of the parties (pleadings)

4. Reaching the verdict (secret consultation)

5. Disclosure of the sentence.

The consultation regarding the verdict may, as mentioned above, only relate to the actions delineated in the bill of indictment. The verdict may only be based on cognitions gathered in the main trial (section 127 par. 2 StPO-BS). However, the court is not bound by the legal judgement of the facts. ${ }^{26}$ If the court wants to base the verdict on other criminal regulations than the PPS has proposed, the court has to point out this to the accused and he has to get the opportunity to defend himself (section 127 par. 2 StPO-BS).

\footnotetext{
${ }^{22}$ E.g. testimonies, minutes regarding sensual perceptions.

${ }^{23}$ E.g. translators, experts.

${ }^{24}$ E.g. when reading out psychiatric expertises or hearing medical experts.

${ }^{25}$ E.g. testimony regarding a sexual offence.

${ }^{26}$ E.g.: If the PPS accuses a person of having committed a severe assault, the court may convict of attempted murder.
} 
Table 2 Number of appeals in criminal cases, thereof confirmed (http://www.statistik-bs.ch)

\begin{tabular}{llllll}
\hline & 2001 & 2002 & 2003 & 2004 & 2005 \\
\hline Appeals in criminal cases $^{\mathrm{a}}$ & $79(100 \%)$ & $85(100 \%)$ & $69(100 \%)$ & $44(100 \%)$ & $98(100 \%)$ \\
Thereof: verdict confirmed & $36(45.6 \%)$ & $30(35.3 \%)$ & $22(31.9 \%)$ & $26(59.1 \%)$ & $26(26.5 \%)$ \\
\hline
\end{tabular}

Persons being subject to penal order or verdict, completion by settlement, withdrawal or cease of the legal remedy included.

Appeals

\section{General Remarks}

There are two restrictions regarding appeals. The appeal authority can alter the contested verdict to the disadvantage of the convicted only if even the PPS has appealed (section 164 par. 1 StPO-BS). ${ }^{27}$ Moreover, the PPS may not make a complaint under constitutional law because this kind of appeal is only for indicating violations of fundamental rights. Surely, these rights are rights of natural persons. Corporate bodies have these rights only if particularly ensured so.

If the PPS makes an appeal to the advantage of the person sentenced, the decision may never be changed to his disadvantage (section 164 par. 2 StPO-BS). If the convicted has appealed, the verdict may only be confirmed or be altered to his advantage, but never to his disadvantage (section 164 par. 2 StPO-BS).

\section{“Appellation” (sections 173-183 StPO-BS)}

Only verdicts and orders for withdrawal of the prosecution made by the first court of law the criminal court - can be appealed. The convicted as well as the PPS are entitled to appeal. The latter may do so to the disadvantage as well as to the advantage of the condemned. The appeal is made by written declaration which has to be handed in to the criminal court. The appeal has to be made within ten days after receiving the written court decision or substantiated judgement. The proceedings in the court of appeal are mostly in written form.

Table 2 outlines the number of appeals in 2001-2005 and shows how many verdicts of the first court of law have been confirmed by the court of appeal.

\section{The "Verzeigung" Proceedings (Penal Order Proceedings)}

The penal order procedures are simplified proceedings. On the one hand, breaches are the subject of such proceedings, i.e. offences carrying the threat of a fine. ${ }^{28}$ On the other hand, single offences carrying a threat of imprisonment, which are listed in a decree issued by the cantonal government (section 5 par. 1 and 2 StPO-BS) are dealt with by penal order proceedings as well. If more serious crimes are present beside the above-named offences, the prosecution is carried out by the PPS in the form of public proceedings.

The investigating authority within the "Verzeigung" proceedings is not the PPS in all cases but the authority in whose area of responsibility the enforcement of the violated

\footnotetext{
${ }^{27}$ Proscription of reformatio in peius. This means that no decision should be amended, in the course of appeals, in a way that is unfavourable to the person who files an appeal.

28 Till 31 December 2006, offences with a threat of detainment or fine.
} 
criminal regulations falls. The responsible authority can be the PPS - regarding violations of the Criminal Code or other legislation such as the Narcotics $\mathrm{Act}^{29}$ - but also even an administrative agency in its area of responsibility. The building supervisory department is responsible for prosecuting violations of Building Law, the cantonal police for dealing with violations of Road Traffic Regulations. Thus the cantonal police have initiated 28,683 criminal proceedings in 2004 which means $75.1 \%$ of all "Verzeigung" proceedings at criminal court. In 200525,183 violations of criminal law where dealt which by such penal order proceedings which is $69.5 \%$ of all correlating proceedings at criminal courts. The cantonal government designates the responsible administrative authorities. If no special authority has been designated, the cantonal police are competent for the prosecution.

The authority does not have the same powers as the PPS. It can drop proceedings (section 5 par. 3 and section 132 par. 2 StPO-BS) ${ }^{30}$ and acts as prosecutor in court (section 5 par. 3 StPO-BS). However, orders regarding coercive measures ${ }^{31}$ demand corresponding requests to the PPS or the judge responsible for arrest matters.

The examining authority carries out the preliminary proceedings and collects evidence in accordance with the regulations of public prosecution. ${ }^{32}$ If the authority does not drop the case, the penal order judge is involved. The incriminated person has to be informed. Moreover, the examining authority can require a regular main trial carried out in criminal court. This happens when the punishment to be imposed exceeds the area of responsibility of the penal order judge $\mathrm{e}^{33}$ as well when the facts of the case are too complex too be dealt with by penal order proceedings (section 134 par. 3 StPO-BS).

If the facts of the case are sufficiently clear and the culpability is not dubious, the penal order judge issues a penal order. Fines, imprisonment up to three months, pub bans, levying and appropriation of confiscated assets in the victim's interest as well as publication of the sentence can be imposed. Furthermore, it can be determined whether a former suspended sentence has to be enforced or waived. A conditionally imposed sanction can only be adjudged enforceable if the sanction does not exceed six months. Other sanctions can only be imposed by the criminal court. The penal order just names the criminal action and the legal regulations applied as well as the sanction. In addition the right to appeal is explicitly named (section 137 StPO-BS). In 2004, 37,488 cases (98.1\%) ended by issuing a penal order. In 2005, the number diminished to 35,279 (97.3\%).

The penal order court can refer the proceedings back to the penal order authority, e.g. when the files are not sufficient for issuing a penal order, or forward them to the criminal court, for instance if the appropriate sanction exceeds the penal order court's competence.

If the affected person does not agree with the penal order, an appeal ("Einsprache") can be made. Herewith the case is handed over to the regular court, i.e. a single judge. The time limit for an "Einsprache" is ten days. As a consequence of the appeal the penal order becomes a bill of indictment and a trial is scheduled by the single judge. The appeal can be recalled until the beginning of the main trial. If the appellant does not appear in court, the appeal is considered to be revoked.

While $725(1.9 \%)$ proceedings were dealt with by trial in 2004, one year later 965 $(2.7 \%)$ cases were ended in this way.

\footnotetext{
${ }^{29}$ E.g. drug consumption.

${ }^{30}$ See at IV.

31 E.g. custody.

32 The examining authority is only obliged to subpoena the accused if this is required by him.

33 This can be the case when "Vergehen" (offences between serious crime and trespass) have to be judged.
} 


\section{Cases Dealt with by the Prosecution Service}

\section{Dropping of Cases (Sections 109-110 StPO-BS)}

If no sufficient suspicious facts result from preliminary proceedings which prove a punishable action or if they evidence that the accused is innocent, the proceedings have to be stopped. In contrast to the court who may acquit of a charge in case of doubt, the PPS may not. The PPS has only the power to decide whether it is obvious from the start that for lack of sufficient clues a condemnation may never be made by court.

The PPS can also drop the proceedings due to irrelevance of the offence according to section 21 StPO-BS and art. 52 StGB (Swiss Criminal Code) ${ }^{34}$ or when no necessity to prosecute exists due to other punishment (section 21 StPO-BS) ${ }^{35}$. Whilst the Code of Criminal Procedure in general is based on the principle of legality, section 21 StPO-BS provides for a temperate (restricted) principle of opportunity.

Furthermore, according to art. $54 \mathrm{StGB}$ a drop of the case is appropriate if the accused is so stricken by the immediate consequences of the offence that an additional punishment would be inadequate.

The proceedings have to be suspended temporarily if no suspect can be detected or if other obstacles do not allow a trial in court temporarily. ${ }^{36}$ The decision to drop the case but not the decision to suspend the proceedings — has to be announced to the participants of the proceedings. ${ }^{37}$ The PPS drops or suspends approximately $70 \%$ of all treated cases (Ruckstuhl 2005).

The accused, the persons who reported the crime, injured persons and victims can appeal the case-ending decision within ten days by a handing over a "Rekurs"38 to the "Rekurs chamber" of the criminal court. This kind of appeal is the demand to carry out normal criminal proceedings and of charging the accused (section 167 par. 1 StPO-BS). The appeal must be written und substantiated.

If the "Rekurs chamber" accedes to the appeal, the PPS is ordered to charge and to present the case to the court to allow an appraisal; or the PPS has to investigate further and afterwards to decide whether to drop or charge (section 172 par. 4 StPO-BS).

\section{Police}

\section{Organization}

The cantonal police is roughly subdivided into four divisions:

- centralized services

- security division

- traffic division

- border guard and search police/investigation.

\footnotetext{
${ }^{34}$ The consequences of the crime are very small.

${ }^{35}$ The criminal action carries no weight in comparison with a punishment or measure which is expected anyhow or an additional punishment is deemed inadequate beside a final decision due to pettiness of the further offence.

${ }^{36}$ E.g. inability of the accused to attend the trial due to illness.

${ }^{37}$ Accused person, person who reported the offence, injured party, victim.

${ }^{38}$ A Rekurs is an appeal on technical issues.
} 
The police of the Canton Basel-Stadt is named "Kantonspolizei" ("canton's police"). This police is not to be confused with the "Kriminalpolizei" ("criminal police", CID). Such a police division does not exist in Basel-Stadt within the cantonal police in contrast to adjoining cantons. The CID in Basel is part of the PPS, it is called "Kriminalkommissariat" (above named as CID/KriKo) although the staff come from the cantonal police. The different subordination has several consequences. The most important impact is that the CID is bound by the regulations of the Code of Criminal Procedure while the Police Law applies for the cantonal police. Tasks and competences differ from Police to Criminal Procedure Law.

As a rule, the repression task (prosecution) is assigned to the CID while the prevention work (averting of danger) is assigned to the cantonal police.

\section{Duties of the Cantonal Police}

The police have to guarantee public peace and order. As soon as a crime is committed, the police are authorized to intervene and obliged to ensure legitimate conditions. The police are not restricted to fulfilling their tasks on their own territory only. Art. 360 StGB determines the power of persecution ${ }^{39}$.

The police have different ways and means to comply with their duties. On the one hand, the law fixes quite a number of concrete measures which can be taken by the police. These measures can be divided into non-custodial ${ }^{40}$ and custodial actions ${ }^{41}$. On the other hand, there is a so-called police blanket clause (section 9 PolG - Police Act). This clause authorizes the police to subject persons to measures which are not expressly named in the Police Act if this is deemed necessary to master an emergency.

The principle of legality and the duty to report (section 99 StPO-BS) cause the police to report to the PPS all offences which became known during official actions. The cantonal police acts in criminal investigations, under the authority of the PPS. Exceptions are made on the one hand in road traffic, where the police are authorized to collect evidence and to punish in accordance with the list of road traffic penalties after a breach of traffic rules or an accident occurs. On the other hand, the police have the power to take all necessary action (in particular, where loss of evidence is imminent) immediately following the discovery of an offense (section 3, Para 1, StPO-BS). In the course of investigations, further tasks and assistance can be entrusted to the police (section 3 par. 2 StPO-BS).

\section{Direct Imposition of Fines by Police Bodies (section 142 StPO-BS)}

The Road Traffic Act and the regulatory statutes belonging to it provide for a direct imposing and collecting of fines by the cantonal police. ${ }^{42}$ In 2004 , this happened in 297,488 cases, whereas 348,517 cases where dealt with as such in 2005 . The same powers were granted by the cantonal government to the cantonal police and other administrative authorities regarding petty violations of cantonal or confederate law. The fines may not

\footnotetext{
${ }^{39}$ I.e. the cantonal police may persecute traced persons beyond the own canton's territory to stop and capture the persons in an adjoining canton.

${ }^{40}$ Personal check, proof of identity, search of persons, vehicles and other objects.

${ }^{41}$ Police arrest, temporary detention, bringing forward.

${ }^{42}$ E.g. parking fines, fines for excessive speed.
} 
exceed CHF 300,-. Moreover, the facts of the case have to be clear and the concerned person has to agree. That implies that the affected person does not object to the fine but pays the fine within the timeline ${ }^{43}$ prescribed. If the payment is not made by the due date, the authority which ordered the fine assumes that the concerned person does not agree with the fine and initiates the "Verzeigungsverfahren" (penal order proceedings). ${ }^{44}$ In 2004 18,447 cases which relate to road traffic were ended by penal order proceedings. This number decreased in 2005 to 15,051 .

\section{PPS Function in Investigative Proceedings}

The PPS received 29,530 reports in 2003, 30,394 in 2004 and 26,413 in 2005. From 2004 until 2005 there is a trend of regression of crime by $13.1 \%$. It has to be taken into account that the principles of criminal statistics have changed by introducing a new computerized data processing system. On the one hand, offences are captured now by time of the offence and no longer by time of reporting. All offences which were reported in the year under review but committed in the year before are not included in the current statistics. On the other hand, the proceedings are not captured anymore, the occurrences have become the basis for the statistics. ${ }^{45}$ So the validity of the statistics differs in content compared with the previous years. Capturing the reports analogously, 27,945 proceedings are present, which means a decrease of $8.1 \%$. The reduction of the cases to be dealt with which is caused by the decrease of the reports was not significant enough to cause a perceptible easing of the PPS workload. The high number of cases is still compelling the PPS to set priorities in processing criminal proceedings and partly causes lengthy proceedings. Moreover, less serious cases cannot always be handled with the resources which are necessary for a comprehensive clear-up (Verwaltungsbericht 2005).

Preliminary proceedings are guided by the PPS. This means that the PPS has to investigate a suspicion by collecting and examining evidence for and against the suspicion, to decide at the end whether the case has to be ended (temporarily or definitely) or an indictment has to be brought in which case the principle "in dubio contra reum" 46 has to be considered. In order to guarantee an objective clarification, the PPS is in principle obliged to be strictly neutral and has to investigate exonerating facts with the same tenacity as circumstances which incriminate the accused (cf. section 22 par.1 last sentence StPO-BS). To carry out this clarification, the PPS as master of the proceedings can give all orders necessary for the preliminary proceedings to be carried out. Exceptionally, some prominent actions may not be ordered by the PPS itself. Their execution requires a permit from the judge who is competent for custody matters ${ }^{47}$, as ordering ${ }^{48}$ or extending detention, a permit for secret surveillance and operations of undercover investigators (whereby this

\footnotetext{
${ }^{43}$ Normally 30 days.

${ }^{44}$ See III.2.2.

${ }^{45}$ Even if several proceedings have to be carried out against different offenders on account of one crime this is not found in the statistics. Only one reporting is included in the statistics.

${ }^{46}$ In case of doubt, facts will be assessed in a way that is unfavourable to the defendant.

47 The oneness of investigation officer and prosecutor has lead to difficulties regarding the detention competences due to art. 5 no. 3 European Convention on Human Rights which had to be remedied by inaugurating a special "custodial judge". This judge decides upon realization and persistence of custody.

${ }^{48}$ If an arrested person cannot probably be released within $48 \mathrm{~h}$ after detention, the person has to be brought before the custodial judge to get a decision upon a warrant of custody.
} 
Table 3 Appeals against custody, thereof rejected (http://www.statistik-bs.ch)

\begin{tabular}{|c|c|c|c|c|c|}
\hline & 2001 & 2002 & 2003 & 2004 & 2005 \\
\hline Appeals against custody ${ }^{1}$ & $15(100 \%)$ & $22(100 \%)$ & $33(100 \%)$ & $20(100 \%)$ & $27(100 \%)$ \\
\hline Thereof: rejected & $8(53.3 \%)$ & $16(72.2 \%)$ & $26(78.8 \%)$ & $18(90 \%)$ & $18(66.7 \%)$ \\
\hline
\end{tabular}

${ }^{1}$ Dispatched cases; completion by settlement, withdrawal or cease of the legal remedy included.

power was granted to the PPS as well until the introduction of the custody judge in 1994). The presidents of the criminal courts become rotational the judges responsible for decisions regarding to custody.

Table 3 gives a summary of appeals against custody between 2001 and 2005 as well as the amount of appeals rejected.

There is no code of criminal procedure determining what has to be done in preliminary proceedings. The reason is that one expects the clarification of suspicion with regard to solid evidence to be quite clear. That is done by seeking and collecting evidence. The evidence regulations define how this has to be performed. Evidence can be divided into personal and objective evidence. Witnesses, informants, the accused and experts belong to personal evidence. Objective evidence means sensual perception, documentary evidence, the stolen goods, traces ${ }^{49}$, operations of liaison officers and technical surveillance ${ }^{50}$.

The principles of free assessment of evidence and of substantive verity lead to the principle of free evidence inquiry. There are no numerus clausus $^{51}$ of evidence. Everything can be evidence if this serves the substantive verity, which comes close to the truth. Thus evidence may only be collected in compliance with the law. So evidential requirements ${ }^{52}$ have to be respected.

A check and control function is assured by a PPS-internal objection procedure (section 166 StPO-BS) and by another, external procedure, which rules that any appeal decision of the leading public prosecutor after a "Rekurs" appeal was made can be captured and transferred to the "Rekurs" chamber of the criminal court.

\section{Particular Issues}

\section{Victim Aid Act}

The Confederate Act on Aid for Victims of Criminal Offences of 4 October 1991 ("Opferhilfegesetz", OHG) is legally effective since 1 January 1993 and regulates, as well as improves on a considerable scale, the position of the injured party and their relatives relating to offences against the physical, sexual or psychical integrity for the whole of Switzerland. The aid includes advice, protection, the preservation of rights during criminal proceedings as well as claims for reparation and satisfaction against the state. The

\footnotetext{
${ }^{49}$ Finger/ear prints, DNA, fibres, footprints, material underneath the fingernails etc.

${ }^{50}$ Post, telephone.

51 Any means of evidence are available, without technical restrictions.

52 E.g.: Confession after beguilement, physical or psychical force.
} 
PPS, the cantonal police or the advice centre informs the victim of his rights. Now the three rights mentioned above shall be specified.

\section{- Advice according to $\mathrm{OHG}$}

The right to obtain advice exists independently whether the victim has reported to the police or does so. The advice is free of charge, the victim can make use of it anonymously. It does not matter whereto the experience of violence dates back. The staff of the advice centres have the duty of discretion against authorities and private persons.

\section{- Special rights within criminal proceedings}

Beside other rights, the injured person may be accompanied by a person in a position of trust. The victim has the right not to be confronted with the offender, to be informed about the state of the proceedings and of exclusion of the public during the trial in court.

\section{- Claim of financial support under certain conditions}

Persons affected by violence have a claim for financial help regarding to costs arisen directly by the crime. The help is subsidiary, so it will be paid only if neither the perpetrator nor an insurance bear the costs. The application has to be made within two years after the offence.

\section{Juvenile Law}

There is no special juvenile criminal code in Switzerland which contains the whole juvenile criminal law along with procedural regulations. Principally, the regular criminal code destined for adults applies for juveniles in the country as well. Alternative clauses with regard to age and sanction were regulated in a separate section till 31 December $2006 .{ }^{53}$ The procedural law is - correlating to the adults - still fixed in cantonal law.

Criminal law for juveniles is special law. It is a perpetrator-oriented penal law, where the person of the child or of the juvenile is in the foreground. Its aim is the prevention of repetitions of an offence and the provision of support to as well as the social integration of the perpetrator. Which reaction may be most appropriate, has to be decided according to the general rehabilitative principles of juvenile justice (i.e. the personality of the juvenile defendant rather than the seriousness of the offense). Thereby the law names three groups of minor criminals: offenders who are exceedingly needy regarding educational care, those who are needy regarding special treatment und other ("normal") perpetrators. On account of these regulations the juvenile law distinguishes further between corrective methods, special (therapeutic) treatment and punishment. If the juvenile prosecutor deems a danger for child or juvenile excluded or not relevant, the proceedings are ended by a punishment. The same happens, if no other measure is available to prevent future degradation. When measuring out the punishment, offence and guilt become important besides the personality and

$\overline{53}$ On 1 January 2007 the Juvenile Criminal Code ("Jugendstrafgesetz", JStG) has become legally effective. 
attempts are made to apply the punishment as an individual preventive solution. The law names the following sanctions ${ }^{54}$ :

- Reprimand

- Fine

- Labor service

- Confinement

The juvenile law has an important particularity compared with the adult law because it offers the opportunity of convicting the juvenile of an offence but to suspend the decision on the sanction for a fixed time. This kind of case-ending decision is made when the judge is not sure, even after all necessary clarification regarding the person of the juvenile, whether a measure or a punishment is adequate.

This suspension is not possible when a child, more exact a person younger than 15 years, is the offender. In this case the rapid and final completion of the proceedings is urgent.

The last opportunity which is also known only in juvenile law is the full waiver of punishment or measure. This may happen for instance when a sanction is from an educational point of view no longer deemed necessary and sensible. ${ }^{55}$ It can be waived as well if the child shows sincere repentance and has made good the damage in accordance with his abilities, on his own initiative. Finally, a waiver can be made if the offence was a long time ago. ${ }^{56}$

The authority carrying out the criminal proceedings against under-age ${ }^{57}$ criminals (at the age of 7 up to 18 years) from reporting to the sentence or the transfer to the court is the juvenile prosecution service.

Specially-trained social and forensics workers carry out the interrogations and other investigative actions which affect the victims. The proceedings are finished by decision or verdict of the juvenile prosecutors ${ }^{58}$ or they are transferred to the criminal court to be assessed. In practice, in nearly all of the cases the juvenile prosecutor himself suggests a verdict. This happened in 2004 in 1,195 cases (97.5\%), thereof 960 (80.3\%) related to breaches and $235(19.7 \%)$ to "normal" offences and serious crimes. In 2005, 969 cases (96.7\%) were counted, thereof 743 breaches (76.7\%) and $226(23.3 \%)$ crimes. In cases where corrective measures or imprisonment exceeding one month shall be imposed, the juvenile criminal court is responsible for judgement. It has imposed 30 verdicts $(2.5 \%)$ in 2004, in 200533 (3.3\%). During the trial, the principle of immediacy does not apply normally, i.e. all judges have already read the files and know the history of the juvenile standing in front of them from these files.

\footnotetext{
${ }^{54}$ Since the beginning of 2007 the following penalties may be imposed on juvenile offenders: a reprimand, a personal work order, fines of up to CHF 2,000 (for 15 to 18 year-old offenders), a custodial sentence of up to 1 year (for 15 to 18 year-old offenders), a custodial sentence of up to 4 years (for 16 to 18 year-old offenders who have committed a serious felony) The Juvenile Criminal Code also envisages the following protective measures: supervision, personal care, outpatient treatment, placement (in the care of private individuals or in an educational establishment or an institution).

${ }^{55}$ E.g. the child has been punished by the parents or other measures have been taken.

${ }^{56}$ Concerning children: three months; Juveniles: one year.

${ }^{57}$ Not to be confused with the responsible age in criminal law. That age is attained upon completion of the seventh year.

${ }^{58}$ In this case the juvenile prosecutor has the function of a judge of a juvenile court.
} 


\section{Current Changes}

\section{Swiss Code of Criminal Procedure}

The discussion about the unification of the criminal procedure law traces back to the time of inception of the Swiss Criminal Code in 1942. At that time the question already arose whether the procedural law should be unified besides the substantive law. This idea was not pursued further. However, the requirement for uniform rules of procedures has grown in the last years. This is expressed by the efforts made by the cantons to ease the procedural intercourse beyond the canton's borders. So all cantons joined the agreement concerning assistance in law enforcement and cantonal co-operation. In addition to this, the confederation has enacted laws in important fields, as to the position of the victim in criminal trial, post surveillance and wire tapping, operations of undercover investigators and use of DNA profiles. Furthermore, it is obvious that the fragmentation of the law increasingly obstructs an effective prosecution due to the increased appearance of cross-border crime. This applies namely to newer types of crime as, e.g. money laundering, organized crime and economic crime (Bundesrat 2006). The newly amended art. 123 par. 1 of the Federal Constitution provides the necessary constitutional basis for the confederation to regulate - besides the substantive law - now the procedural law as well. On 21 December 2005, the Federal Council passed a message to unify the codes of criminal procedure as well as two bills. ${ }^{59}$

The draft of a Swiss Code of Criminal Procedure is based on the PPS model II. The decision in favour of this model has been influenced by the fact that all cantons or states, ${ }^{60}$ having amended their codes of procedure or having decided to do so, have adopted this model. This PPS model bears the advantage of achieving a high grade of efficiency of prosecution by realizing homogenous investigation, examination and charging. Moreover, the PPS carrying out the investigation from the beginning to charge avoids dual proceedings as conditioned by the alternate work of examining magistrate and the PPS. These advantages are faced with a downside of a concentration of powers and so a burden of responsibility on the PPS's side. The strong position of the PPS shall be compensated by court responsible for compulsory acts and extended defence powers. Furthermore, as an additional balance, the principle of immediacy is foreseen (Bundesrat 2006).

The Federal Code of Criminal Procedure provides for new regulations which were not known or only known in some cantons so far, such as:

- the extension of the principle of opportunity which allows the law enforcement authorities to waive prosecution in special cases

- an understanding between victim and offender in terms of a settlement or a mediation as well as agreements between accused and PPS regarding guilt and punishment

- reinforcement of defence powers as admission of the "lawyer of the first hour", the right to call in a defender at any stage of the proceedings, the right to keep silent

- the position of the injured party in the proceedings is regulated capaciously and partly strengthened in comparison with the present-day regulations in the $\mathrm{OHG}$

- extension of the witness protection program to all people being heard during the proceedings excluding the accused

- monitoring of bank accounts as a new compulsory measure

\footnotetext{
${ }^{59}$ A Swiss Code of Criminal Procedure and a Swiss Code of Juvenile Criminal Procedure.

${ }^{60}$ E.g. Italy, Austria.
} 
The criminal proceedings referring to juvenile offenders are regulated by an own code which contains all the regulations differing from those in the StPO (Swiss Code of Criminal Procedure). Even in the scope of juvenile criminal judicature the prosecution is committed to a specialized judicial authority's care during all stages. The juvenile judge is judging authority for petty and moderately-serious crime. In the rare case of serious crime the judicial assessment is incumbent upon the juvenile court.

\section{Criminal Code (StGB)}

On 1 January 2007, the general part of the Swiss Criminal Code became legally effective. The juvenile law has been detached from the Criminal Code and regulated in a separate federal code. The age of criminal responsibility has been raised from seven to ten years. Juveniles from the age of 16 on may be punished by imposing imprisonment up to four years after having committed a very serious crime. If the relevant authority ascertains during proceedings that an offence has been committed before the 10th birthday, the legal representatives of the child must be informed. If there are indications of a special demand for assistance, the guardianship authority is notified. "Young adults" (persons aged between 18 and 25 years) do not exist anymore in law. If a person commits a crime over the age of 18, he/she will be treated as an adult (Bundesrat 1999).

\section{The Victim Aid Code}

Evaluations of victim assistance centres in the years 1993-1998 have shown that a complete review of the code is necessary. The Federal council has passed the message on total revision of the Victim Aid Code on 11 November 2005. Aim of the revision is to improve the applicable law, to assay innovations and to limit expenditures. The three-pillars concept $^{61}$ of the applicable law is to be retained. However, regulations regarding the protection of the victim within criminal proceedings will be incorporated in the new Swiss Code of Procedure. The satisfaction for sustained nuisance is to be retained as well, but there is a ceiling on it. Providing benefits after an action committed abroad induces many problems in practice. It is frequently difficult to determine the facts of the case and to decide whether an offence has been committed or not. So the principle of territory has been embedded (Bundesrat 2005). This imports that in case of crimes abroad responsibility for compensation and satisfaction will be passed on. Victims and their relatives who reside in Switzerland can lay claim to benefits from the advice centres which can freely be chosen. The time limit has been extended from two years to five years. A special regulation applies for underage victims of serious crime, especially violations of sexual integrity. They can file an application up until the age of 25. Furthermore, the long-term aid of the advice centres is assigned much more strongly towards achieving compensation. Both instruments overlapped in the past. The bill provides for granting long-term advice as long as the physical condition has become stable and the other consequences of the crime have been erased or balanced out as far as possible, whereas compensation includes the cost for medical cure and care after stabilizing the state of health as well as losses due to unemployment, the loss of a provider and funeral costs. The duty of discretion shall be softened ${ }^{62}$ and a right to inspect the files is to be newly incorporated.

\footnotetext{
${ }^{61}$ Advice, financial support and protective rights during the proceedings.

${ }^{62}$ The advice centres shall be allowed to report to the guardianship or prosecution authority if there is a serious jeopardy of the underage victim or another underage person becoming affected by new offences (e.g. in the case of a paedophile teacher or domestic violence).
} 


\section{References}

Bundesrat (1999). Botschaft zur Änderung des Strafgesetzbuches vom 21.09.1998. Bern: Bundeskanzlei.

Bundesrat (2005). Botschaft zur Totalrevision des Bundesgesetzes über die Hilfe an Opfer von Straftaten. Bern: Bundeskanzlei.

Bundesrat (2006). Botschaft zur Vereinheitlichung des Strafprozessrechts vom 21. Dezember 2005. Bern: Bundeskanzlei.

Elsner, B., \& Peters, J. (2006). The criminal justice system in Germany. In Jehle J.-M. \& Wade M. (Eds.), Coping out overloaded criminal justice systems. Springer.

Ruckstuhl, N. (2005). Strafprozessrecht. Vorlesungsskript Juristische Fakultät der Universität Basel, Wintersemester 2005/2006.

Ruckstuhl, N., Maglia, M., \& Aebersold, P. (1998). Ratgeber Strafverfahren Basel-Stadt. Basel: Verein Neustart.

Hauser, R., Schweri, E., \& Hartmann, K. (2005). Schweizerisches Strafprozessrecht, 6. Auflage. Basel: Helbing \& Lichtenhahn.

Verwaltungsbericht des Regierungsrates und Bericht des Appellationsgerichts über die Justizverwaltung und Bericht des Ombudsman vom Jahre 2005 an den Grossen Rat des Kantons Basel-Stadt

\section{Legal documents}

Swiss Criminal Code of 21 December 1937 (Schweizerisches Strafgesetzbuch vom 21. Dezember 1937).

Code of Criminal Procedure of the Canton Basel-Stadt of 8 January 1997 (Strafprozessordnung des Kantons Basel-Stadt vom 8. Januar 1997).

Police Act of the Canton of Basel-Stadt of 13 November 1998 (Gesetz betreffend die Kantonspolizei des Kantons Basel-Stadt vom 13. November 1998).

Victim Aid Code of 4 October 1991 (Opferhilfegesetz vom 4. Oktober 1991).

Law on the organisation of the Courts (Gesetz betreffend Wahl und Organisation der Gerichte sowie der Arbeitsverhältnisse des Gerichtspersonals und der Staatsanwaltschaft).

By-law of 6 December 2005 on the tickets to be handed out on the spot by the police officers (Verordnung über die direkte Erhebung von Bussen für Übertretungen des baselstädtischen Rechts vom 6. Dezember 2005).

By-law of 22 September 1969 on the supervision of PPS (Reglement betreffend Beaufsichtigung der Staatsanwaltschaft durch den Regierungsrat unter Mitwirkung der Justizkommission vom 22. September 1969).

By-law of 16 December 1997 on the powers of the PPS (Verordnung über die Befugnisse innerhalb der Staatsanwaltschaft vom 16. Dezember 1997).

By-law of 6 June 2000 on the organisation of the PPS (Amtsordnung der Staatsanwaltschaft (und allgemeines Geschäftsreglement) vom 6. Juni 2000).

Statistics. http://www.statistik-bs.ch/ 